\title{
Granice ingerencji turystyki surwiwalowej w tereny przyrodnicze o różnym reżimie ochronnym
}

\author{
Przemysław Płoskonka ${ }^{1 *}$, Paweł Adamski ${ }^{2}$, Szymon Ciapała ${ }^{3}$ \\ ${ }^{1}$ Wydział Turystyki i Rekreacji, Akademia Wychowania Fizycznego Józefa Piłsudskiego w Warszawie \\ ${ }^{2}$ Instytut Ochrony Przyrody PAN w Krakowie \\ ${ }^{3}$ Wydział Turystyki i Rekreacji, Akademia Wychowania Fizycznego im. Bronisława Czecha w Krakowie \\ * przemyslaw.ploskonka@awf.edu.pl
}

\section{Streszczenie}

Surwiwal jako forma turystyki i rekreacji wymaga dostępu do zasobów przyrodniczych, w tym tych o wysokim stopniu naturalności. Obszary te ze względu na walory przyrodnicze i funkcje środowiskowe podlegają różnym reżimom ochronny. W artykule dokonano analizy obowiązujących regulacji prawnych oraz oceniono wpływ poszczególnych rodzajów zajęć z surwiwalu na obszary przyrodnicze. W konkluzji stwierdza się, że regulacje prawne stanowią istotny czynnik warunkujący możliwość uprawiania surwiwalu na terenie Polski, podejmowanie tej formy aktywności musi odbywać się przy ścisłej współpracy z właścicielami oraz zarządzającymi terenów, zaś stopień ingerencji w środowisko naturalne jest uzależniony od tematyki zajęć oraz czasu ich trwania.

\section{Słowa kluczowe}

surwiwal, wpływ turystyki, regulacje prawne, tereny chronione

\section{Wstęp}

Turystyka i rekreacja stanowią dynamicznie rozwijającą się gałąź gospodarki i jako takie wymagają dostępu do szeroko pojętych zasobów (Briassoulis 2002: 1065-1068). W niektórych opracowaniach jako „zasób” traktowane jest też sama obecność terenów o wysokim stopniu naturalności (Sinclair 1971: 263). W polskojęzycznym piśmiennictwie turystycznym używa się jednak raczej terminu „walor” lub „walor naturalny"/"przyrodniczy", przy czym, w zależności od kontekstu może on mieć nieco różne znaczenie (Kruczek 2002: 38-41, Lijewski et al. 2002: 73-75). Niezależnie jednak od szczegółów klasyfikacyjnych można przyjąć, że tereny o wysokim stopniu naturalności stanowią niezbędny element do rozwoju niektórych form rekreacji - głównie turystyki przyrodniczej (Adamski, Ciapała 2016: 11-14, 20-21, Beczkowska 2003: 9-12). Jednak użytkowanie turystyczne zawsze wiąże się $\mathrm{z}$ ingerencją $\mathrm{w}$ istniejący układ ekosystemów, a co za tym idzie stwarza potencjalne ryzyko ich destabilizacji (Liddle 1997: 1-636). $\mathrm{Z}$ tego powodu na obszarach o wysokich walorach przyrodniczych wprowadza się różnego rodzaju regulacje służące minimalizacji ryzyka wystąpienia strat w środowisku przyrodniczym. W Polsce na terenach objętych 
ochroną w postaci parków narodowych i rezerwatów oraz na obszarach lasów państwowych powszechną praktyką jest kanalizowanie ruchu turystycznego na szlakach, ścieżkach przyrodniczych oraz powszechnie dostępnych miejscach zaopatrzonych w różnego rodzaju elementy infrastruktury rekreacyjnej takie jak ławki, wiaty, toalety miejsca na ogniska i tym podobne (Ciapała et.al. 2010 s: 78-80; Kikulski 2011: 290, Muszyński i Kozioł 2012: 109-110). Rozwiązania takie zwykle nie są jednak satysfakcjonujące dla osób parających się niektórymi formami rekreacji. Dotyczy to przede wszystkim turystyki przyrodniczej (Adamski, Ciapała 2016: 13), która w wielu wypadkach wymaga dotarcia do terenów nieatrakcyjnych dla innych grup turystów lub wręcz nieudostępnianych turystycznie (Sekercioglu 2002: 283-284, Lee et al. 2010: 696, 702-703). Inną, dynamicznie rozwijającą się formą rekreacji związaną $\mathrm{z}$ terenami o niskim nasyceniu infrastrukturą turystyczną jest surwiwal. Niestety ta forma aktywności, mimo że od dawna praktykowana i posiadająca specyficzne wymagania, wydaje się być niedoceniana zarówno przez zarządzających atrakcyjnymi dla surwiwalu terenami jak i przez osoby badające relacje między turystyką a środowiskiem przyrodniczym.

\section{Surwiwal identyfikacja zjawiska}

Słownik języka polskiego PWN definiuje surwiwal (z ang. słowa survival - przetrwanie, przeżycie) jako pokonywanie trudno dostępnych i niebezpiecznych terenów, związane $\mathrm{z}$ samodzielnym zdobywaniem pożywienia, traktowane jako sport lub element szkolenia żołnierzy jednostek specjalnych (web-01). Ta definicja jest dalece niewystarczająca i na potrzeby niniejszej pracy należy ją uściślić i sprecyzować.

Surwiwal w potocznym rozumieniu utożsamiany jest z umiejętnościami pozwalającymi przetrwać w trudnych warunkach, w związku z tym nazywany jest również sztuką przetrwania i traktowany jako zbiór wiedzy o postępowaniu we wszystkich sytuacjach opresyjnych, skrajnie uciążliwych, ekstremalnych (Płoskonka, 2015: 752-753). Tom Brown Jr. (1987) identyfikuje pojęcie surwiwalu w dwóch kategoriach znaczeniowych: pozostanie przy życiu do czasu przybycia pomocy (jak przeżyć) oraz życie w dziczy (jak żyć). Podobnie - ogólnie - przedstawia kwestię Hans Otto Meissner, który twierdzi, iż surwiwal to „umiejętność przetrwania na łonie dzikiej natury dobrowolnie bądź też w sytuacji przymusowej" (Meissner 1990: 5). Wedle najlapidarniejszych ujęć surwiwal jest umiejętnością przystosowania do nowych okoliczności i warunków (Pękała 1998: 77-86), lub po prostu rodzajem samoratownictwa (Kwiatkowski 2009: 17-29). John Wiseman zauważył, że „umiejętność przeżycia w warunkach odmiennych od normalnych podnosi się do rangi sztuki, nazywając ją surwiwalem" (Wiseman 2001: 14-15)

Surwiwal traktowany jako sztuka ${ }^{1}$ przetrwania jest umiejętnością adaptacji do warunków zewnętrznych oraz zdolnością optymalnego wykorzystania dostępnych zasobów - szczególnie naturalnych, do osiągnięcia zamierzonych celów (por. Płoskonka, 2015: 752-753). Bolesław Uryn dopowiada jeszcze jedno wyjaśnienie. Aby dać sobie radę $\mathrm{w}$ nowym środowisku, musimy się przystosować lub bronić się przed jego szkodliwym oddziaływaniem. W tym celu niezbędna jest wiedza o zagrożeniach i pozwalających je ograniczyć metodach działania. Trzeba zwiększyć możliwości naszego organizmu, ale znać też granice jego wytrzymałości - i to właśnie nazywa „sztuką przetrwania" (Uryn 2003: 7-8). Colin Towell zaznacza jeszcze, iż w przypadku „sztuki przetrwania obowiązuje zasada, by minimum zużytej energii przyniosło maksymalny zysk" (Towell 2012: 6-7, 10). Kwiatkowski (2009: 17-29) podkreśla, iż w terminie sztuka przetrwania określenie „sztuka” pozwala zaznaczyć tę szczególną umiejętność posługiwania się wiedzą prakseologiczną,

1 Sztuka (łac ars.) rozumiana jako umiejętność wymagająca szczególnych zdolności, biegłość w robieniu czegoś (web-02). 
gdyż dotyczy jak najsprawniejszego zaspokajania życiowych potrzeb przy jak najmniejszych nakładach własnych oraz twórcze podejście do szukania rozwiązań.

\section{Surwiwal jako forma aktywności turystyczno-rekreacyjnej}

Współcześnie surwiwal jest złożoną formą aktywności, realizowaną w wielu różnorodnych modelach. Istnieje tendencja do tego, by każdy rodzaj działalności, w tym ruchowej, związany z ryzykiem, wymagający improwizacji i niosący ze sobą duży ładunek emocji, nazywać surwiwalem. W związku z tym zjawisko to należy rozpatrywać co najmniej dualnie. Po pierwsze, jako element edukacji obronnej, przygotowanie żołnierza do działań militarnych. Surwiwal jest więc traktowany jako sposób przygotowania fizycznego w szkoleniu obronnym żołnierzy (Groskrejc 1996: 34-39). Jest również - patrząc z innej perspektywy - jednym z elementów treningu militarnego.

Sztuka przetrwania dla żołnierzy sprowadza się do zagadnień związanych zarówno z utrzymaniem życia w warunkach izolacji od własnych sił wojskowych oraz innych jednostek i zbiorowości ludzkich, jak i kwestii konieczności podjęcia walki o przetrwanie z siłami, które dążą do pojmania żołnierza lub pozbawienia go życia (Kalina i in. 2002: 397-404).

Po drugie, jako jedną z form turystyki i rekreacji dwóch przejawów działalności ludzkiej, których rozróżnienie bywa dość trudne. Literatura dotycząca sfery turystyczno-rekreacyjnej uznaje surwiwal za rodzaj aktywności przygodowej mający związek z rozwojem turystyki kwalifikowanej (w Polsce) i rekreacji przygodowej (na świecie). Już kilka lat temu Włodzimierz Kurek (Kurek 2007: 256-278) zauważył, że jedną z nowych i zyskujących na popularności form turystyki przygodowej jest turystyka przetrwania - surwiwal. Zwracał uwagę na to, że ta formuła łączy w sobie element przygody, związany z koniecznością przetrwania w trudnych warunkach, $\mathrm{z}$ aktywnym wypoczynkiem, a także zapewnia bliski kontakt z przyrodą. Uczestnicy w trakcie takich wypadów uczą się m.in. zasad organizowania wyprawy oraz doboru ekwipunku, posługiwania się sprzętem potrzebnym do przetrwania, budowania schronień, udzielania pierwszej pomocy oraz wzywania pomocy, pokonywania przeszkód terenowych, orientacji w terenie, zdobywania i przyrządzania pożywienia, rozpalania ognia. Turystyka surwiwalowa spełnia także ważne funkcje psychologiczne. Pozwala uczestnikom na sprawdzenie się oraz ukształtowanie predyspozycji psychicznych i fizycznych podczas przystosowywania się do trudnych warunków, a w konsekwencji prowadzi do wzmocnienia wiary we własne możliwości.

Surwiwal postrzegany jako przedsięwzięcie turystyczne Płoskonka (2015: 760-761) definiuje jako dobrowolną formę spędzania czasu wolnego w plenerze ${ }^{2}$, mającą na celu przeżycie przygody, połączonej ze zdobywaniem wiedzy i ćwiczeniem umiejętności związanych z przetrwaniem w warunkach opresyjnych, w tym naturalnych czyli pozbawionych ułatwień, które niesie ze sobą cywilizacja. Istotą tej aktywności jest uzyskanie niezależności od czynników cywilizacyjnych oraz zwiększenie sprawności działania poprzez poznanie mechanizmów adaptacji do zmiennych wpływów środowiska.

Surwiwal w Polsce nie jest zupełnie nową formą aktywności turystyczno-rekreacyjnej wyprawy realizujące w pewnym stopniu ideę surwiwalu organizowały już w latach 50. XX wieku Komisje Turystyki Górskiej PTTK w Warszawie i Krakowie. Były to tzw. obozy wędrowne turystyki kwalifikowanej, zwanej również wysoko kwalifikowaną. Jak zauważa Czarnowski (2002: 52) zajęcia takie odbywały się głównie w Bieszczadach

2 Plener - słowo pochodzące $\mathrm{z}$ ang. open air, plein-air, oznaczające otwartą przestrzeń pod gołym niebem bądź naturalną scenerię będącą miejscem aktywności artystów (web-03). Z czasem zaczęto określać tym terminem miejsce także innych form aktywności. Można zatem przyjąć, iż w działalności turystyczno-rekreacyjnej plener jest elementem środowiska przyrodniczego, którego aktualny stan można uznać za dostatecznie bliski naturalnemu. 
i Beskidzie Niskim, zaś wędrówka trwała 2 tygodnie i odbywała się m.in. w ramach kursów dla kandydatów na przodowników GOT - nazywano je „wyrypami". Dzikie tereny górskie, chaszcze, rwące rzeki, błotniste bezdroża i odludzia wymagały znacznego wysiłku, celowo dobranego ekwipunku i sporej wiedzy turystycznej. Trasy tych wypraw były specjalnie utrudniane, np. marszem na przełaj w poszukiwaniu określonych celów, biwakowaniem "na dziko” oraz wyznaczaniem zadań specjalnych. Uczestnicy uczyli się technik wędrówki i przetrwania w naturalnych warunkach, testowali własne możliwości, rozładowywali stres - a wszystko w poczuciu przeżywania życiowej przygody. Niemałe znaczenie miała dla nich także satysfakcja z odkrywania nieznanych zakątków oraz obcowanie ze wspaniałą przyrodą

Jak podkreślał Zieliński (1976: 35-36) urok wyrypy polegał na tym, że wiesz tylko jedno: skąd wychodzisz i dokąd chcesz dotrzeć. Czy cel osiągniesz, gdzie będziesz nocował i na którym boku - o tym dowiesz się później, gdy wrócisz do domu. Ani ty, ani najbardziej doświadczony z twoich towarzyszy nie jesteście w stanie przewidzieć rozwoju wypadków. Z własnej, nieprzymuszonej woli będziesz się pchał $\mathrm{w}$ gardło trudnościom, będziesz borykał się z wiatrem, kurniawą, mgłą i lodem. I co najważniejsze, będziesz tym wszystkim zachwycony. Wyrypy bywają różne, tak różne, jak różne są dnie w górach. Czasem jest to rozkoszny spacer w pełnym blasku słońca. Innym razem uparta walka o każdy metr terenu przy wtórze wichru. Czasami wreszcie - rozpaczliwa walka o życie.

Na podstawie dostępnej literatury Płoskonka (2015: 760-761) podjął próbę wyróżnienia współczesnych form uprawiania surwiwalu (tab.1)

Na potrzeby niniejszej pracy przeanalizowano dostępne wyniki badań nt. surwiwalu jako formy aktywności turystyczno-rekreacyjnej. Niestety w bogatym dorobku nauk

3 Wyrypa - wymagająca wędrówka, długodystansowy marsz górski (web-04). o kulturze fizycznej jest niewiele prac dotyczących aktywności surwiwalowej. Zdecydowana większość autorów skupia się na technicznych aspektach surwiwalu pomijając zagadnienia związane z uwarunkowaniami tej aktywności. Nieliczne prace badawcze oparte były przeważnie na obserwacji, zaś materiał badawczy stanowiła niewielka liczba osób. $Z$ dostępnych badań opisujących to zagadnienie można wyciągnąć następujące wnioski.

Preferowanym środowiskiem uprawiania surwiwalu - rozumianego jako zespołu elementów środowiska naturalnego oraz elementów pozaprzyrodniczych, które zdaniem uczestników sprzyjają aktywności surwiwalowej, były odludne obszary leśne z urozmaiconym ukształtowaniem terenu i bliskością zbiorników wodnych (Płoskonka 2015: 9597, Zarzycki i Opoka 2007: 110-116). Dodatkowym atutem była dziewiczość i dzikość przyrody. Uczestnicy zajęć skupiają się na walorach przyrodniczych, mniejsze znaczenie mają walory antropogeniczne, zaś najmniej istotna okazała się dostępność bazy noclegowo-gastronomicznej. Można zatem wnioskować, iż miejsce realizacji zajęć jest silnie uwarunkowane dostępnością środowiska przyrodniczego umożliwiającego zdobywanie w nim różnych nowych doświadczeń.

Czas trwania jednorazowego wyjazdu surwiwalowego najczęściej wynosił 2-3 dni, ze wskazaniem na weekend. Oznacza to, że surwiwalowcy spędzają 1-2 noclegi w terenie, wyjazdy dłuższe (ponad 4 dni) odbywały się sporadycznie. Potwierdzają to pozostałe dane - do najpopularniejszych form uprawiania należały wycieczki jednodniowe i wielodniowe z noclegiem (Płoskonka 2015: 95-97). Warto również zauważyć, iż sposób organizacji zajęć wskazuje na dużą samodzielność uczestników. Zajęcia surwiwalowe najczęściej są organizowane indywidualnie lub z grupą znajomych i kolegów.

Istotne jest również sprecyzowanie treści zajęć z surwiwalu. Wiedza, jaką powinien dysponować surwiwalowiec, nie stanowi treści jednej dziedziny naukowej, musi zawierać $\mathrm{w}$ sobie elementy $\mathrm{z}$ wielu dziedzin 
Tabela 1. Formy uprawiania surwiwalu (Płoskonka 2015: 760-761)

\begin{tabular}{|c|c|}
\hline Forma surwiwalu & Charakterystyka \\
\hline Wycieczka terenowa & $\begin{array}{l}\text { Przechadzka, przejażdżka lub wypad jednej bądź większej liczby osób poza miejsce zamieszkania } \\
\text { w celach nauki i/lub ćwiczenia bądź doskonalenia wybranych technik przetrwalnych, poznania } \\
\text { nowego terenu. Najczęściej dotyczy aktywności jednodniowej i weekendowej. }\end{array}$ \\
\hline Obóz stacjonarny & $\begin{array}{l}\text { Forma aktywnego wypoczynku grupy ludzi związana z uprawianiem surwiwalu, nauką nowych i/ } \\
\text { lub ćwiczeniem już posiadanych umiejętności przetrwalnych. Organizacyjnie przybiera najczęściej } \\
\text { formę zespołu namiotów lub innego typu schronień usytuowanych pod gołym niebem, } \\
\text { z prowizorycznym zapleczem kuchennym i sanitarnym. Najczęściej trwa od } 5 \text { do } 12 \text { dni i może } \\
\text { przybierać charakter wakacyjny. }\end{array}$ \\
\hline Obóz wędrowny & $\begin{array}{l}\text { Wędrówka piesza z lekkim sprzętem obozowym, namiotami i przyborami kuchennymi, a często } \\
\text { także z żywnością. Uczestnicy obozu wędrownego sami przyrządzają posiłki, zakładają obóz oraz } \\
\text { ćwiczą elementy surwiwalu. Najczęściej przybiera charakter wakacyjny i trwa od } 5 \text { do } 8 \text { dni. }\end{array}$ \\
\hline Rajd, bieg terenowy & $\begin{array}{l}\text { Wędrówka co najmniej kilku grup turystyczno-surwiwalowych po określonym terenie, w trakcie } \\
\text { której cały zespół realizuje zaplanowane zadania o charakterze surwiwalowym, wyszczególnione } \\
\text { w regulaminie. Ważnym elementem jest współzawodnictwo pomiędzy zespołami. Może } \\
\text { występować również rywalizacja indywidualna. Czas trwania rajdu / biegu terenowego, który może } \\
\text { odbywać się o dowolnej porze roku, to 1-2 dni. }\end{array}$ \\
\hline Zlot, konwent & $\begin{array}{l}\text { Impreza, w której biorą udział zarówno grupy zorganizowane, jak i uczestnicy indywidualni. Celem } \\
\text { zlotu jest dotarcie do wyznaczonej miejscowości i pobyt w niej w celu wymiany surwiwalowych } \\
\text { doświadczeń, spotkania z fachowcami z dziedzin sztuki przetrwania, prezentacji osiągnięć, planów } \\
\text { itp. Czas trwania: 1-3 dni, pora roku: dowolna. }\end{array}$ \\
\hline Warsztaty, kurs & $\begin{array}{l}\text { Zajęcia teoretyczno-praktyczne doskonalące umiejętności z wybranego zakresu sztuki surwiwalowej } \\
\text { bądź dotyczące ogólnie tej formy turystyki. Celem szkolenia prowadzonego przez instruktorów jest } \\
\text { podnoszenie kompetencji surwiwalowych uczestników. Kursy mogą być połączone z uzyskaniem } \\
\text { uprawnień instruktorskich. Czas trwania (o dowolnej porze roku): warsztaty - od kilku godzin do } \\
3 \text { dni, kursy - ok. 90-100 godzin dydaktycznych (6-8 dni). }\end{array}$ \\
\hline
\end{tabular}

- wszystkie służące przetrwaniu. Jacek Pałkiewicz (1998: 8-9) do najważniejszych z nich - tzw. fundamentów sztuki przetrwania zalicza m.in. umiejętność budowy schronienia, rozpalania ognia, pozyskania wody i żywności oraz znajomość zasad sygnalizacji. Przeprowadzone badania potwierdzają, iż do preferowanych treści związanych z surwiwalem należą budową prowizorycznych schronień, rozpalaniem ognia i konstruowaniem ognisk oraz terenoznawstwem i przemieszczanie się $\mathrm{w}$ terenie. Pozostałe istotne treści zajęć prezentuje poniższa tabela.

\section{Wpływ surwiwalu na środowisko przyrodnicze}

Aby określić w jaki sposób, wymienione w tabeli 2, treści szkoleń mogą oddziaływać na środowisko przyrodnicze, konieczne jest ustalenie z jakimi konkretnymi działaniami są one związane

W oparciu o badania dotyczące oddziaływania ruchu turystycznego na przyrodę Liddle 1997, Hodden 2008: 3-23, 65-118 oraz obowiązujące w Polsce przepisy regulujące zasady postępowania na terenach chronionych oraz przyrodniczo cennych, przygotowano zestawienie regulacji prawnych odnoszących się do konkretnych aktywności podejmowanych przez osoby parające się surwiwalem. Ze względu na różnice w reżimach ochronnych regulacje rozpatrzono osobno dla 3 kategorii terenów:

1. Parki narodowe i rezerwaty przyrody. Zasady udostępniania tych obszarów są jasno sprecyzowane w Ustawie o ochrony przyrody (A). Szczególnie ważny jest art. 151 wymieniający 26 zakazów domyślnie obowiązujących 
Tabela 2. Wybrane preferencje treści zajęć z surwiwalu (Płoskonka 2015: 95-97)

\begin{tabular}{|c|c|}
\hline Zagadnienia podstawowe & Treści \\
\hline Schronienie & $\begin{array}{l}\text { budowa schronień z wykorzystaniem zarówno posiadanego sprzętu, jak i naturalnego } \\
\text { terenu i naturalnych materiałów zabezpieczanie się przed niekorzystnymi warunkami } \\
\text { atmosferycznymi. }\end{array}$ \\
\hline Ogień & $\begin{array}{l}\text { zasady doboru terenu i budowania różnego rodzaju ognisk rozpalanie ognia w różnych } \\
\text { warunkach terenowych i różnymi sposobami }\end{array}$ \\
\hline Terenoznawstwo & $\begin{array}{l}\text { nawigacja przy pomocy mapy i busoli, wyznaczanie azymutów, tworzenie szkiców } \\
\text { terenowych, posługiwanie się GPS-em, wykorzystywanie środowiska naturalnego do } \\
\text { orientacji w terenie, określania stron świata oraz nawigacji }\end{array}$ \\
\hline Pionierka obozowa & budowa prowizorycznych narzędzi oraz urządzeń obozowych \\
\hline Tropienie & $\begin{array}{l}\text { badanie życia fauny na określonym obszarze } \\
\text { rozpoznawanie gatunków zwierząt, specyfika ich zachowań }\end{array}$ \\
\hline Roślinoznawstwo & $\begin{array}{l}\text { rozpoznawanie gatunków roślin jadalnych i leczniczych oraz sposoby ich zbierania } \\
\text { i przygotowania do spożycia }\end{array}$ \\
\hline Zdobywanie i pozyskiwanie żywności & $\begin{array}{l}\text { zdobywanie i przygotowywanie prostego pożywienia, łowienie ryb, przechowywanie } \\
\text { i utrwalanie żywności }\end{array}$ \\
\hline Woda & $\begin{array}{l}\text { pozyskiwanie, odkażanie i transport wody w terenie, minimalizacja strat wody } \\
\text { z organizmu }\end{array}$ \\
\hline Posługiwanie się linami & $\begin{array}{l}\text { techniki i sprzęt improwizowany, robienie węzłów, pokonywanie przeszkód terenowych } \\
\text { (za pomocą lin), przeprawy linowe }\end{array}$ \\
\hline Meteorologia & podstawy prognozowania pogody terenie \\
\hline kucznictwo & podstawy budowy i zastosowania łuku \\
\hline Sygnalizacja & sposoby komunikacji na odległość, zasady wzywania pierwszej pomocy \\
\hline
\end{tabular}

na terenach objętych tymi formami ochrony. W regulaminach konkretnych parów narodowych i rezerwatów niektóre z zakazów mogą zostać złagodzone lecz nie dotyczy to zasadniczej zasady ogólnej. W przypadku pozostałych form ochrony przyrody nie ma ujednoliconych zasad

2. Lasy. Duża część działań związanych z rekreacją oraz innymi formami wykorzystania terenów leśnych jest uregulowana zapisami ustawy „o lasach" (B). W wielu punktach ustawa odwołuje się do właściciela lub zarządzającego terenem jako podmiotu mogącego wyznaczać treny do niektórych form rekreacji (biwakowanie, palenie ognisk itp.) bez rozróżnienia na formę własności lasu - państwową, samorządowo, wspólnotową czy prywatną. Jednak z praktycznego punktu widzenia sensowne wydaje się rozróżnienie na Lasy Państwowe, dla których opracowane są spójne i łatwe do odnalezienia oraz lasy o innych formach własności.

3. Inne tereny ogólnie dostępne. Do celów surwiwalu atrakcyjne są zwykle tereny różnego rodzaju nieużytków oraz zadrzewień nie stanowiących formalnie lasów. Dla terenów takich nie opracowano osobnych regulacji należy więc odnosić sie do przepisów o charakterze ogólnym takich jak Kodeks wykroczeń (C), przepisy przeciwpożarowe (D) i (E), oraz Prawo Wodne (F)

Niezależnie od kwestii regulacji prawnych dla działań związanych uprawianiem surwiwalu, przedstawiono analizę potencjalnego wpływu na środowisko przyrodnicze.

\section{Nocowanie bez budowy schronień}

Na pierwszy rzut oka działanie to wydaje się nieszkodliwe, stąd pewne zdziwienie może budzić fakt, że poza miejscami wyznaczonymi jest ono zakazane zarówno w parkach 
narodowych, rezerwatach przyrody (A: art $15 \$ 1$ p. 23$)$ jak i w lasach (B: art $30 \$ 1$ p. 23). Jednak, pomijając możliwość uszkodzenia roślin przez śpiącą na nich osobę (B: art $156 \$ 1$ ), już sama obecność turysty może przyczynić się wpływać na zachowanie zwierząt. Niekoniecznie musi oznaczać ucieczkę przepłoszonego osobnika - często reakcja ogranicza się do zwiększenia poziomu stresu lub większej czujności. (Dyck, Baydak 2004: 344-348 ). Skutkuje to jednak zmniejszeniem intensywności żerowania i karmienia potomstwa, co może wpływać na przeżywalność zimy lub sukces reprodukcyjny (Carney, Sydeman 1999: 73-74, Martin, Réale 2008: 69-71). Warto podkreślić, że ssaki niepokojone mogą być również przez sam zapach człowieka lub zwierząt domowych (Duncan et al. 2002: 2631, Gutzwiller 1990: 251-252, Treves, Naughton-Treves 2005: 99). Właśnie z tego powodu na obszarach ochrony ścisłej i czynnej parków narodowych oraz rezerwatach przyrody obowiązują całkowite zakazy wprowadzania psów (A: art. $15 \$ 1$ ), który w planach ochrony może zostać uchylony lub rozciągnięty na cały obszar PN.

\section{Poruszanie się poza wyznaczonymi szlakami}

Jest kluczowe dla większości działań związanych z aktywnością surwiwalową. Na terenach parków narodowych i rezerwatów przyrody jest ono objęte całkowitym zakazem $^{[3]}$. Na obszarach nie objętych tymi formami ochrony przyrody zastosowania mają ogólne przepisy ogólne. Przede wszystkim chodzi o art. 157 \$1 Kodeksu Wykroczeń (C) brzmiący "Kto wbrew żadaniu osoby uprawnionej nie opuszcza lasu, pola, ogrodu, pastwiska, taki lub grobli,podlega karze grzywny do 500 złotych lub karze nagany." Konstrukcja przepisu wskazuje, że w przypadku terenów nieogrodzonych istnieje rodzaj „domniemania zgody” na wejście, a sankcją obłożone jest jedynie nie zastosowanie się do wyraźnego żądania właściciela. Sytuacja taka dotyczy jednak wyłącznie terenów nieogrodzonych i nie stanowiących upraw rolnych. Wejście na teren uprawy traktowane jest jako jej niszczenie, obłożone sankcją przez art. $156 \mathrm{KW}(\mathrm{C})$. Z kolei wtargnięcie na cudzy, ogrodzony teren przestaje być wykroczeniem, a staje się przestępstwem przeciwko art. $193 \mathrm{KK}$ (G). Warto zwrócić uwagę, że ustawodawca nie określa sposobu ogrodzenia co może niekiedy prowadzić do nieporozumień.

Na terenie lasów stanowiących własność skarbu państwa można poruszać się poza szlakami i drogami z wyłączeniem terenów objętych zakazem wstępu zgodnie z $\mathbb{\$} 2$ i $\mathbb{\$} 3$ artykułu 26 ustawy o lasach (B). Ustawodawca nakłada na służby leśne obowiązek oznakowania objętymi zakazem wstępu terenów odpowiednimi tablicami zawierającymi przyczynę wprowadzenia zakazu, a w przypadku zakazów innych niż stałe termin ich obowiązywania. Właściciele lasów innych niż należące do Skarbu Państwa mają także prawo całkowicie zakazać wstępu do swojego lasu informując o tym przez wywieszenie tablic. Pod względem wpływu na środowisko przyrodnicze poruszanie się poza szlakami i drogami może być uciążliwe ze względu na płoszenie zwierząt omówione przy rozważaniach kwestii biwakowania.

\section{Pozyskiwanie gałęzi lub młodych drzewek}

$Z$ jednej strony jest to ważny element działań survivalowych, kluczowy dla budowania schronień, prowizorycznych mebli i narzędzi oraz zaplecza kuchennego. Pod względem prawnym jest to czynność całkowicie zabroniona w parkach narodowych i rezerwatach przyrody - choć ustawa nie wspomina wprost o gałęziach, ale o „częściach roślin” (A: art. $15 \$ 1$ p. 13). Wprawdzie literalna interpretacja zapisu ustawy sugeruje możliwość wyznaczenia miejsc, w których pozyskanie takie byłoby dozwolone, jednak trudno wyobrazić sobie praktyczne wprowadzenie takiej zasady. $\mathrm{Na}$ terenach lasów kwestie pozyskiwania gałęzi i krzewów reguluje zapis art $148 \$ 1$ Kodeksu Wykroczeń (C: art. $148 \$ 1$ ), penalizującego takie działania osób nie będących właścicielami lasów (C: art. $153 \$ 1$ ). Zatem z prawnego punktu widzenia działania takie muszą odbywać się 
za zgodą właściciela lasu, w przypadku LP reprezentowanego przez służby leśne. Mniej jasna jest kwestia działań takich na terenach nieśnych - Kodeks wykroczeń penalizuje uszkadzanie drzew lub krzewów owocowych (C: art. $150 \$ 1$ ), a także sadzonek, zasiewów i trawy (C: art. $156 \$ 1$ ) nie wspominając o innych rosnących na tym terenie krzewach lub drzewach. Należy w tym miejscu wspomnieć, że w myśl obowiązujących przepisów usunięcie drzewa o obwodzie poniżej $10 \mathrm{~cm}$ nie stanowi wycinki. Dużo bardziej skomplikowana jest kwestia przyrodniczych efektów pozyskiwania gałęzi lub drobnych pojedynczych drzewek. Oczywiście każda taka czynność wiąże się z uszkodzeniem drzewa. Prowadzi do zmniejszenia funkcjonalnej powierzchni asymilacyjnej, oraz otwarcia dróg infekcji przez organizmy pasożytnicze (Rykowski 1974: 15-16, Stańczykiewicz 2006: 92, 111-112). Z drugiej jednak strony przemyślane przycinanie gałęzi pozwala na kształtowanie pnia w sposób zwiększający późniejszą przydatność drzewa do celów produkcyjnych lub innych. W młodnikach proces wczesnych czyszczeń, polegający na usunięciu części drzew jest standardową procedura pozwalającą na uzyskanie w przyszłości drzewostanu o pożądanych parametrach (Gazda, Karaś 1994: 65-68). Podobnie niejednoznaczna jest kwestia pozyskiwania niedużych samosiejek na nieużytkowanych terenach rolnych - zabieg ten nie tylko może powstrzymywać sukcesję ekologiczną, która stanowi zagrożenie dla wartościowych przyrodniczo terenów nieleśnych (Witkowski et al 2004: 52-54).

\section{Pozyskiwanie większych drzew}

W tym przypadku sprawa jest prosta; pozyskanie drzewa bez wiedzy i zgody właściciela jest po prostu kradzieżą lub uszkodzeniem mienia, a więc czynem zabronionym, a jego klasyfikacja jako przestępstwa lub wykroczenia zależy od wartości ściętego drzewa $(\mathrm{C}$ art. $120 \$ 1$ ).

\section{Zbieranie chrustu i posuszu}

Działanie kluczowe dla biwakowania połączonego z paleniem ognia oraz przygotowywania pożywienia. Pod względem prawnym jest regulacje są niejasne. Zbierania chrustu nie zostało wymienione expicite verbis w ustawie o ochronie przyrody ani ustawie o lasach czy kodeksie wykroczeń. Może ono jednak być utożsamiane ze „zbieraniem gałęzi” zabronionym na terenie cudzych lasów przez art. 154 KW (C) lub „zbioru części roślin” wspomnianego w art $13 \$ 1$, pkt 13 ustawy o ochronie przyrody (A) - ustawodawca nie precyzuje bowiem ani stanu wspomnianych części roślin ani tego kiedy zostały oddzielone. KW (C) w art. $120 \mathbb{\$}$ nie precyzuje również stanu ściętego przez inną osobę lub powalonego drzewa, w związku z tym przywłaszczenie go stanowi wykroczenie niezależnie od tego w jak daleko posuniętym stanie rozkładu się ono znajduje. Z przyrodniczego punktu widzenia kwestią zasadniczą jest rozmiar suchych drewna. O ile bowiem drobny chrust jest w zasadzie jedynie fragmentem materii organicznej to już grubsze konary czy pnie stanowią ważne siedlisko dla wielu grup organizmów grzybów, śluzowców, owadów oraz innych stawonogów (Piotrowski 2010: 2-10, Solon 2002: 969-960, Gutowski i Buchholz 2002: 50-51, 69-70), a pośrednio także zwierząt owadożernych- ptaków, płazów, gadów i ssaków (Bartnik 2007: 535-537; Zawadzka, Zawadzki 2006: 257). Spalanie takiego drewna sprawia, że staje się ono pułapką ekologiczną dla bytujących w nim organizmów, niekiedy o ogromnej przyrodniczej wartości (Adamski et al. 2016: 1100-1101, Gutowski, Buchholz 200o: 69-70). Szkodliwe może być także przemieszenie takiego materiału w miejsce o innych warunkach wilgotności, temperatury czy nasłonecznienia. Pociąga to bowiem za sobą zmianę warunków mikrosiedliskowych w obrębie samego drewna (Gutowski Buchholz 2000: 50-54). Generalnie można przyjąć zasadę, że im większa średnica i rozmiar drewna tym większe prawdopodobieństwo, że stanowi on siedlisko cennych gatunków. 


\section{Pozyskiwanie grzybów, roślin zielnych i zwierząt}

Może ono mieć na celu uzyskanie pożywienia lub półproduktów do wyrobu narzędzi. Z punktu widzenia przepisów prawa wydzielić należy gatunki łowne. Zasady ich pozyskiwania określane są przez dwie ustawy: z 18 kwietnia 1985 r. O rybactwie śródlądowym. (H) oraz z 13 października 1995 r. Prawo łowieckie (I) (z późniejszymi zmianami), a także wydane do nich przepisy wykonawcze. Równie jasna jest sytuacja gatunków objętych ochroną prawną - ich pozyskiwanie w ramach surwiwalu jest nielegalne. Wspomniane w art. 51 ust. 2 oraz 52 ust. 2 (A: art. 51 ust 2 oraz art. 52 ust 2) odstępstwa od związanych z ochrona gatunkową zakazów nie maja bowiem zastosowania w rekreacji. Teoretycznie szkoła przetrwania, lub instruktor nie zostali w żaden sposób wykluczeni spośród podmiotów mogących wystąpić o zgodę, na pozyskiwanie gatunków chronionych. Trudno jednak założyć by podmiot taki był w stanie przedstawić akceptowalne dla GDOŚ uzasadnienie. W przypadku gatunków nie objętych ochroną, możliwości ich pozyskiwania uzależnione są od statutu obszarów - na obszarach parków narodowych i rezerwatów przyrody jest to zakazane (A: art. $15 \$ 1$ ). Na terenie lasów nie objęte ochroną gatunkową rośliny zielne i grzyby, zaliczane są do tzw. "owoców runa leśnego" mogą być wykorzystywane na potrzeby własne (B: art. 27). Przy czym zbiory te nie mogą być prowadzone na terenach objętych zakazem wstępu (B: art. 26) oraz w sposób powodujący uszkodzenie runa, wymagający rozkopywania ściółki oraz niszczenie grzybni (B: art. 30) oraz metod uznanych za zakazane droga rozporządzenia Ministra odpowiedniego do spraw środowisk (B: art. $27 \$ 5$ ).

W przypadku lasów nie stanowiących własności skarbu państwa przepisy dotyczące zbioru płodów runa są nieprecyzyjne: z jednej strony Ustawa o lasach wspomina tylko o udostępnianiu do zbiorów lasów państwowych, z drugiej jednak KW (C) w art $153 \$ 1$ pkt 4 wspomina jedynie o "miejscach” lub „sposobach” zabronionych. Sugeruje to, że w lasach niepaństwowych, jeżeli właściciel nie ustanowił zakazu wstępu obowiązują przepisy takie same jak w LP. Jest to o tyle dziwne, że w tym samym artykule KW (C) w pkt. 3 za zabronione uznaje się zbieranie w nieswoim lesie wiórów, szyszek i ziół. W tym momencie pojawia się też problem czym - w przepisach dotyczących udostępniania lasów - różnią się „zioła” od „roślin zielnych".

Brak jest zakazów pozyskiwanie zwierząt nie objętych ochroną gatunkową ani łowiecką czy wędkarską. Zakazane jest jednak rozkopywanie mrowisk (B: art $30 \$ 1$ pkt. 11) oraz rozgarnianie ściółki (C: art. 163). Z punktu widzenia przyrodniczego wpływ na środowisko przyrodnicze pozyskania zarówno roślin jak i zwierząt nie objętych ochroną gatunkową zależny jest od skali zjawiska. Biorąc pod uwage polskie realia działania takie podejmowane w ramach surwiwalu są nieistotne $\mathrm{w}$ zestawieniu $\mathrm{z}$ rekreacyjnym lub zarobkowym pozyskiwaniem grzybów i owoców runa.

\section{Prace obozowe i związana z nimi aktywność}

Jest to integralna część surwiwalu, a ze względu na swoją kompleksowość obejmuje ona omówione wcześniej działania. Prócz tego często wiąże się z koniecznością przeprowadzenia drobnych prac ziemnych, czy ingerencji w stosunki wodne. Pod względem prawnym działania takie, są nielegalne w ogóle (C: art. 163) lub wymagają zgody właściciela ternu (C: art. 154 p. 1 i 4) W dużej mierze wynika to $\mathrm{z}$ tego, że w ustawach użyte są pojęcia niesprecyzowane. Dotyczy to np. zakazu kopania „dołu lub rowu” (C: art. 154 p. 1 i 4) bez określenia parametrów, przy jakich uznaje się, efekt pracy łopatą za „dół”. W tej sytuacji dochodzi, w świetle prawa, do zrównania „dołka toaletowego" z wykopami przemieszczającymi wiele metrów sześciennych ziemi. Podobna sytuacja dotyczy pojęcia „zmiany stosunków wodnych" obejmującym zarówno przekierowanie rzeki jak i pogłębienie dna strumyka tak by można się w nim było wygodnie umyć. 
Z przyrodniczego punktu widzenia, za potencjalnie mogące wpłynąć na środowisko przyrodnicze należałoby uznać „prace ziemne", których efekty prowadzą do powstania dołów o pionowych brzegach głębokich na co najmniej $20-30 \mathrm{~cm}$. Takie dołki bowiem mogą stanowić pułapkę na płazy czy niektóre gady. Szczególnie niebezpieczne są sytuacje, gdy powstaje dołek częściowo wypełniony wodą, ale od jej lustra do brzegu pozostaje wysoka na ponad $20 \mathrm{~cm}$ „ściana”. Obecność wody może bowiem przywabiać płazy, które nie będą mogły potem wydostać się z takich wykopów. Mechanizm ten został dobrze opisany na przykładzie wykopów związanych z inwestycjami budowlanymi i drogowymi (Brudzik Wojtas 2011: 26, Kurek et al. 2011: 107-109).

\section{Palenie ognia otwartego}

Można w zasadzie uznać, za jeden z kluczowych elementów uprawiania surwiwalu. Niestety, jest to też aktywność obłożona bardzo wyraźnymi restrykcjami. Co ciekawe, w tej kwestii ustawa o lasach jest bardziej restrykcyjna niż ustawa o ochronie przyrody. Ta pierwsza bowiem zabrania na trenie lasów i w ich otoczeniu używania ognia otwartego płomienia w ogóle (B: art. 30), podczas gdy ustawa o ochronie przyrody zabrania jedynie rozpalania ognisk, palenia tytoniu oraz używania źródeł światła z otwartym płomieniem (A: art. $15 \mathbb{\$}$ p.10). Uzasadnieniem tak silnych ograniczeń jest przede wszystkim zagrożenie pożarowe - w lecie w siedliskach borowych wilgotność ściółki często spada do poziomu niższego niż 10\% (Szczygieł i in. 2009: 95 i 100) podczas gdy za granicę zagrożenia pożarowego uznaje się wartość 30\%, a wg niektórych autorów nawet 60\% (Santorski 1999: 5-8). Oczywiście ryzyko zaprószenia ognia może być minimalizowane przez odpowiednie zabezpieczenie miejsca palenia ognia jak i samą technikę jego rozniecania. Inne potencjalnie szkodliwe działanie używania płomienia np. wypalanie mikrofauny czy mikroflory glebowej- w przypadku niewielkich ognisk surwiwalowych ze względu na swój lokalny i krótkotrwały charakter można uznać za pomijalnie mały.

Ważnym elementem doskonalenia umiejętności survivalowych jest poszerzanie wiedzy przyrodniczej. Jest ono ukierunkowane przede wszystkim na pozyskiwanie informacji dotyczącym unikania zagrożeń lub wykorzystywania elementów środowiska przyrodniczego jako źródła pożywienia, wody czy surowców. Jednak fakt, że wiąże się ono z rozpoznawaniem gatunków, a także zrozumieniem działających w przyrodzie mechanizmów wydaje się być korzystny z punktu widzenia przyrodników.

\section{Podsumowanie}

Obowiązujące regulacje prawne jednoznacznie wskazują, że uprawianie surwiwalu musi odbywać się przy ścisłej współpracy z właścicielami oraz zarządzającymi terenem. Restrykcyjne zapisy regulujące kwestie rekreacji na terenach parków narodowych i rezerwatów przyrody sprawiają, że na terenach tych surwiwal można uprawiać w bardzo ograniczonym zakresie. Jednakże niezależnie od kwestii reżimu ochronnego problemem może być obawa służb leśnych oraz osób odpowiedzialnych za ochronę przyrody w stosunku do osób parających się surwiwalem, postrzeganych jako źródło zagrożeń przyrodniczych (Ciapała et al. 2017: in press). Niezbędne zatem wydaje się wypracowanie mechanizmów współpracy organizatorów imprez i szkoleń surwiwalowych z gospodarzami terenu. Na obszarach leśnych naturalnym partnerem są struktury lasów państwowych - choćby $\mathrm{z}$ tego powodu, że zarządzają one ponad $80 \%$ terenów leśnych , a poza tym mają klarowną jednolitą strukturę organizacyjną. Ze względów formalnych współpraca taka odbywać się powinna przede wszystkim na poziomie nadleśniczego, który odpowiada za gospodarkę leśną oraz stan lasu na terenie swojego nadleśnictwa (B: art. $35 \$ 1$ ). Z punktu widzenia potrzeb osób parających się surwiwalem szczególnie ważna jest kwestia możliwości biwakowania oraz używania ognia 
otwartego, które stanowią kluczowe elementy obozownictwa.

Obecnie praktyka stosowana w Lasach Państwowych oraz na trenach objętych ochrona polegała zwykle na wyznaczaniu stałych miejsc biwakowania oraz palenia ognisk. Miejsca te są zwykle łatwo dostępne i przeważnie zaopatrzone w odpowiednią, podstawowa infrastrukturę. Jednak przepisy nie wykluczają możliwości występowania z prośbą o jednorazowe lub okresowe zgody na wyznaczenie miejsc biwakowania, palenia ognisk lub wręcz prowadzenia, zawierających elementy surwiwalu, zajęć na terenach nie objętych zakazami.

Ze strony osób parających się surwiwalem należałoby z kolei oczekiwać podstawowej wiedzy na temat szkód przyrodniczych jakie mogą być wywołane przez ich działanie oraz sposobów ich unikania i minimalizacji. W tym przypadku istotną rolę powinny odegrać programy edukacyjne prowadzone przez Lasy Państwowe oraz upowszechnienie ich w środowisku osób zajmujących się surwiwalem. Wymaga to intensyfikacji kontaktów z organizacjami skupiającymi adeptów sztuki przetrwania oraz podjęcia wspólnych działań na rzecz edukacji przyrodniczej. Przedsięwzięciem, które powinno zyskać uznanie zarządców terenów leśnych jest wdrażana przez Stowarzyszenie Polska Szkoła Surwiwalu edukacja na rzecz odpowiedzialnej turystyki na terenach leśnych, oparta na zasadach Leave no Trace. W niektórych przypadkach można nawet pokusić się próby opracowania schematów postępowania np. ustalenie, które z potencjalnie możliwych do wykorzystania gatunków roślin (np. jadalnych czy leczniczych) ze względu na zagrożenie powinny być traktowane jako „opcja ostatniego wyboru”, z których zaś można korzystać praktycznie bez ograniczeń.

Większe trudności napotykać może kwestia legalizacji i sformalizowania bardziej inwazyjnych elementów zajęć surwiwalowych - np. pozyskiwania małych drzewek. Podczas zabiegów czyszczenia młodników są one w lasach gospodarczych pozyskiwane w znacznych ilościach i traktowane jako odpad - a więc palone lub rozdrabniane (Sadowski et al. 2012: 247) W tej sytuacji nasuwa się możliwość połączenia aktywności surwiwalowej wymagające pozyskania gałęzi lub małych drzewek z prowadzonymi przez leśników pracami. Bezpośredni udział miłośników surwiwalu w pozyskiwaniu takiego materiału jest raczej mało prawdopodobny, ze względu na obowiązujące w miejscach prac leśnych przepisy BHP. Można jednak opracować procedury o wykorzystania do potrzeb surwiwalowych materiału stanowiącego uboczny produkt prac leśnych. Problematyka ta wymaga jednak przeprowadzenia szczegółowej analizy prawnej wykraczającej poza ramy niniejszego artykułu.

W wypracowywaniu zasad współpracy surwiwalowców z podmiotami odpowiedzialnymi za zarządzanie terenem należy pamiętać także o pozytywnych aspektach udostępnienia terenu miłośnikom surwiwalu. Mogą oni bowiem stanowić dla gospodarzy swego rodzaju „system wczesnego ostrzegania" o pojawiających się na ich terenie niebezpiecznych zjawiskach - np. pożarach. Surwiwalowcy penetrując tereny lasów i nieużytków mogą lokalizować ślady działalności kłusowniczej (wnyki itp.), a sama ich obecność może stanowić czynnik odstraszający. Podobny mechanizm może działać w przypadku dzikich wysypisk śmieci lub innych szkodliwych działań - kradzież drewna itp. Dokonywane przez miłośników surwiwalu obserwacje przyrodnicze mogą stanowić cenne uzupełnienie wiedzy przyrodniczej, dla celów naukowych oraz ochroniarskich. Podobne programy funkcjonują od lat w krajach Europy Zachodniej i Ameryki Pn. (tzw. „citizen sicence”) (Silvertown 2009: 467-471). Oczywiście wymaga to, aby osoby parające się surwiwalem posiadały odpowiedni zasób wiedzy przyrodniczej. Dlatego elementy przyrodoznawstwa obecne w szkoleniach surwiwalowych oprócz aspektu użytkowego flory i fauny powinny obejmować także, informacji dotyczące ochrony przyrody. Jest to ważne także dlatego, że zrozumienie sensu niektórych 
ograniczeń ułatwia ich akceptację przez turystów (Adamski et al. 2016: 171-172; Weiler Davis 1993: 94-95). W przypadku surwiwalu wiedza taka może ułatwiać współpracę z podmiotami zarządzającymi terenem.

Podsumowując należy podkreślić, iż Lasy Państwowe dostrzegają potrzebę udostępniania terenów leśnych dla surwiwalowców. Na stronie Leśnego Przewodnika Turystycznego można dowiedzieć się, iż surowe warunki pociągają ludzi, którzy chcą nabyć umiejętności radzenia sobie w trudnych sytuacjach i próbują, zdobywać pożywienie, znajdować i urządzać miejsce do kilkudniowego pobytu, czy choćby przenocowania. Trwająca już wiele lat moda na szkoły przetrwania sprawia, że w lasach często widuje się małe grupki, głównie młodych ludzi, próbujących przygody z naturą. Jeśli tylko nie szkodzą jej, mogą liczyć na wyrozumiałość, a nawet sympatię ze strony Służby Leśnej (web-05).

\section{Bibliografia}

Adamski P., Bohdan A., Michalcewicz J., Ciach M., Witkowski Z., 2016, Timber stacks: potential ecological traps for an endangered saproxylic beetle, the Rosalia longicorn Rosalia alpina. "Journal of Insect Conservation", 20(6), 1099-1105.

Adamski P. Kolasińska A. Witkowski Z., 2016, Czy zachowanie turystów w Pienińskim Parku Narodowym zależy od ich wiedzy i nastawienia do Parku? Pieniny - przyroda i człowiek 14:167-174

Bartnik C., 2007, Saprotrofy - rola w ekosystemie leśnym oraz możliwosc ich wykorzystania w gospodarce leśnej. Studia i Materiały Centrum Edukacji Przyrodniczo-Leśnej 9 (2-3): 530-540.

Bezkowska G., 2003, Problemy oceny walorów przyrodniczych dla turystyki i rekreacji na obszarze Nizin Środkowopolskich. Turystyka i Hotelarstwo, 4, 9-33

Burdzik R., Wojtas K., 2011, Wpływ rozbudowy systemów transportowych na ekosystemy i dziką faunę. „Zeszyty Naukowe”. Transport/Politechnika Śląska, 21-28.

Briassoulis H., 2002, Sustainable tourism and the question of the commons. Annals of Tourism Research, 29(4), 1065-1085.)
Brown T. Jr., 1987, Field Guide to Wilderness Survival, Penguin Publishing Group, New York City, USA

Carney KM, Sydeman WJ., 1999, A review of human disturbance effects on nesting colonial waterbirds. "Waterbirds" 22, 68-79

Ciapała S., Adamski P., Bielański M., 2017, Survival coraz popularniejsza forma rekreacji i jej wpływ na lasy. Studia i Materiaty CEPL w Rogowie. W druku

Ciapała S., Zielonka T., Kmiecik-Wróbel J., 2010, Metody zapobiegania nielegalnej dyspersji turystów i związanej z nią erozji gleby w Tatrzańskim Parku Narodowym. Folia Turistica 22: 67-90

Czarnowski A., 2002, Survival w PTTK, „Gościniec” 4(8): 52.

Duncan RS, Wenny DG, Spritzer MD, Whelan CJ., 2002, Does human scent bias seed removal studies?. Ecology, 83(9), 2630-2636.

Dyck MG, Baydak RK., 2004, Vigilane behaviour of polar bears (Ursus martimus) in the context of wildlife-viewing activities at Churchill, Manitoba, Canada. „Biological Conservation” 116:343-350

Gazda M., Karaś M., 1994, Wpływ czyszczeń na stan hodowlany i zywotnosc jodel w odsłoniętych młodnikach sosnowych. „Prace Instytutu Badawczego Leśnictwa. Seria B", 20: 61-70.

Groskrejc J., 1996, Specyfika wykorzystania środków kultury fizycznej w przygotowaniu obronnym żołnierzy formacji lądowych Wojska Polskiego [w:] Kalina R. M. (red.) Wychowanie fizyczne w edukacji obronnej społeczeństwa, PTNKF. SKFW, Warszawa: 34-39.

Gutowski, JM, Buchholz, L., 20oo, Owady leśnezagrożenia i propozycje ochrony. Wiadomości entomologiczne 18: 43-72.

Guarino R., Menegoni P., Pignatti S., \& Tulumello S., 2015, A territorial contradiction. In Nature Policies and Landscape Policies (pp. 69-76). Springer International Publishing.

Gutzwiller K.J., 1990, Minimizing dog-induced biases in game bird research. Wildlife Society Bulletin (1973-2006), 18(3): 351-356.

Hodden A., 2008, Environment and Tourism, secoud edition. Routelgade. London, New York,

Jonsell M., 2008, Saproxylic beetle species in logging residues: which are they and which residues do they use?. Nor J Entomol 55:109-122

Kalina R.M., 1997, Szkoła przetrwania (survival) jako formuła ukierunkowanego przygotowania 
psychofizycznego pilotów wojskowych [w:] „Polski Przegląd Medycyny Lotniczej" 4(3): 285-289.

Kikulski, J., 2011, Aspekty udostępniania lasów do celów rekreacyjnych. Studia i Materiaty Centrum Edukacji Przyrodniczo-Leśnej, 13(3 [28]): 288-292. Kruczek, Z., 2002, Atrakcje turystyczne. Metody oceny ich odbioru-interpretacja Folia Turistica, (13), 37-61.

Kwiatkowski K. J., 2009, Sztuka przetrwania - modus vivendi [w:] Bergier J., Sroka M. (red.) Survival w teorii i praktyce, PWSZ im. Papieża Jana Pawła II, Biała Podlaska: 17-29.

Kurek W., 2007, Turystyka. PWN, Warszawa.

Kurek RT, Rybacki M, Sołtysiak M., 2011, Poradnik ochrony płazów. Ochrona dziko żyjących zwierząt w projektowaniu inwestycji drogowych. Pracownia na rzecz wszystkich istot. Bystra

Lee, C. K., Lee, J. H., Kim, T. K., \& Mjelde, J. W., 2010, Preferences and willingness to pay for bir$\mathrm{d}$-watching tour and interpretive services using a choice experiment. Journal of Sustainable Tourism, 18(5), 695-708.

Lijewski, T., Mikułowski, B., \& Wyrzykowski, J., 2002, Geografia turystyki Polski. Polskie Wydawn. Ekonomiczne.

Martin JGA, Réale D., 2008, Animal temperament and human disturbance: implications for the response of wildlife to tourism." Behavioural Processes", 77(1), 66-72

Meissner H.O., 1990, Sztuka życia i przetrwania, tłum. A. Sznaper. Bellona, Warszawa.

Muszyński, Z., \& Kozioł, L., 2012, Innowacyjność w zrównoważonym rozwoju sylwaturystyki. Zeszyty Naukowe Matopolskiej Wyższej Szkoty Ekonomicznej $w$ Tarnowie, 2 (21), 101-112.

Pałkiewicz J., 1998, Survival - sztuka przetrwania. Dom Wydawniczy Bellona, Warszawa.

Pękała T., 1998, Podstawy survivalu (sztuki przetrwania), „Wiedza Obronna” 1: 77-86.

Piotrowski, M., 2010, Martwe drewno w lesie i jego znaczenie dla różnorodności biologicznej ekosystemu. Biblioteczka Leśniczego, 312: 1-12.

Płoskonka P., 2015, Surwiwal jako forma aktywności turystyczno-rekreacyjne - synteza zjawiska. Zeszyty Naukowe Wyższej Szkoły Bankowej we Wrocławiu , vol 15/6: 751-764

Płoskonka P., 2015, Survival - selected determinants of participation. Polish Journal of Sport and Tourism, vol. 22/2: 94-105
Rykowaski K., 1974, Występowanie sinizny w miejscach zawieszania zbiorników żywiczarskich. „Prace IBL” 485:13-42

Santorski Z., 1999, Prognozowanie zagrożenia pożarowego lasów. Metoda IBL. „Biblioteczka Leśniczego" 112: 1-11

Sadowski, J., Moskalik, T., Zastocki, D., Wrona, T., 2012, Wybrane gospodarcze i przyrodnicze aspekty zagospodarowania pozostałości zrębowych. Studia i Materiaty Centrum Edukacji Przyrodniczo-Leśnej, 14(3 [32]), 246-253

Sekercioglu, C. H., 2002, Impacts of birdwatching on human and avian communities. Environmental conservation, 29(3), 282-289.

Sinclair, A. R. E., 1971, Wildlife as a resource. Outlook on Agriculture, 6(6), 261-266.

Silvertown, J., 2009, A new dawn for citizen science. Trends in ecology \& evolution, 24(9), 467-471.

Stańczykiewicz, A., 2006, Poziom uszkodzeń odnowienia w wyniku stosowania ręczno-maszynowych technologii pozyskiwania drewna. Acta Agraria et Silvestria. Series Silvestria, 4.4, 91-116.

Solon J., 2002, Ekologiczna rola martwego drewna w ekosystemach leśnych-dyskusja wybranych zagadnień w świetle literatury. [w:] Podstawy trwatego i zrównoważonego zagospodarowania lasów w Leśnych Kompleksach Promocyjnych (A. Breymeyer, M. Degórski, E. Roo-Zielińska, J. Solon, J. Wolski). IBL, Sękocin Las. s. 948-965

Szczygieł, R., Ubysz, B., \& Piwnicki, J., 2009, Kryteria oceny ryzyka zagrożenia pożarowego lasu. Bezpieczeństwo i Technika Pożarnicza, 37: 83-112.

Treves A, Naughton-Treves L., 2005, Evaluating lethal control in the management of human-wildlife conflict. Conservation Biology Series-Cambridge-, 9, 88-106.

Towell C., 2012, Survival dla każdego, tłum. A. Koper. Solis, Warszawa.

Uryn B. A., 2003, Mój survival z ludzką twarzą, „Survival” (3): 7-8.

Weiler, B., \& Davis, D., 1993, An exploratory investigation into the roles of the nature-based tour leader. Tourism Management, 14(2), 91-98.

Wiseman J., 2001, SAS. Szkoła przetrwania, tłum. A. Bezpiańska-Oglęcka, J. Jedliński, M. Krueger. Muza, Warszawa.

Witkowski Z.J., Michalik S. Adamski P., 2004, Conservation of the marginal areas in protected 
territories: the Ojców National Park - case study. „Ekológia (Bratislava)” 23, 1: 44-56

Wolski J., 2003, Martwe drzewo w lesie: ocena zapasu i propozycje postępowania. „Prace Instytutu Badawczego Leśnictwa. Seria A", (2 [952-955]): 23-45.

Zarzycki P., Opoka D., 2007, Survival jako forma turystyki przygodowej podejmowana przez młodzież Dolnego Śląska [w:] Umiastowska D. (red.), Aktywność ruchowa ludzi w różnym wieku, Albatros, Szczecin: 110-116.

Zawadzka D., Zawadzki J., 20o6, Ptaki jako gatunki wskaźnikowe różnorodności biologicznej i stopnia naturalności lasów. „Studia i Materiaty Centrum Edukacji Przyrodniczo-Leśnej", 8(4):249-262

Zieliński S., 1976, W stronę Pysznej. Państwowe Wydawnictwo „Iskry, Warszawa

Ustawa z dnia 16 kwietnie 2004 "O ochronie przyrody" (z późniejszymi zmianami) Dz. U, $2004 \mathrm{nr}$ 92 poz. 88o; Dz.U z 2016 poz. 2134, 2249, 226o, Dz. U z 2017 poz. 6o, 132, 1074, 1566, 1595

Ustawa z dnia 28 września 1991 o lasach (z późniejszymi zmianami): Dz.U. 1991 nr 101 poz. 444 (Dz. U 2017, poz. 788)

Ustawa z dnia 20 maja 1971 „Kodeks Wykroczeń” (z późniejszymi zmianami): Dz.U. 1971 poz. 1149 Dz.U. 2015 poz. 1094, 1485, 1634, 1707; Dz. U. 2017 poz. 966,1941$)$.

Ustawa z dnia 24 sierpnia 1991 r. o ochronie przeciwpożarowej (z późniejszymi zmianami): Dz. U. 1991, nr 81 poz. 351, (Dz. U. z 2017, poz. 736, 1169)
Rozporządzenie Ministra Spraw Wewnętrznych i Administracji w sprawie ochrony przeciwpożarowej budynków, innych obiektów budowlanych i terenów,Dz.U.2010.109.719

Ustawa z dnia 20 lipca 2017 r. - Prawo wodne. Dz.U. 2017 poz. 1566

Ustawa z dnia 6 czerwca 1997 r. - Kodeks karny. Dz.U. $1997 \mathrm{nr} 88$ poz. 553 (z późniejszymi zmianami): Dz.U z 2016 poz 2134, 2249, 226o, Dz. U z 2017 poz $60,132,1074,1566,1595)$

Ustawa z dnia 18 kwietnia 1985 r. o rybactwie śródlądowym. Dz.U. 1985 nr 21 poz. 91 (z późniejszymi zmianami): Dz. U. 2015 poz 652; Dz. U. 2017. poz 6o, 1566)

Ustawa z dnia 13 października 1995 r. Prawo łowieckie. Dz.U. 1995 nr 147 poz. 713 (z późniejszymi zmianami): Dz. U 2017 poz. 1295)

web-o1 http://sjp.pwn.pl/sjp/survival;257666o dostęp: 30.10.2017.

web-02. https://sjp.pl/sztuka dostęp: 30.10.2017.

web-o3 http://sjp.pwn.pl/szukaj/plener.html dostęp: 30.10.2017.

web-o4 https://sjp.pwn.pl/doroszewski dostęp: 30.10.2017.

web-05 www.czaswlas.pl dostęp:30.11.2017.

\title{
Limits of interference of survival tourism in natural areas with various protective regimes
}

\begin{abstract}
Survival as a form of tourism and recreation requires access to natural resources, including those with a high degree of naturalness. Due to their natural values and environmental functions, these areas are subject to various protection regimes. The article analyzes existing law regulations and assesses the impact of individual types of survival classes on natural areas. The conclusion states that law regulations are an important factor conditioning the possibility of practicing survivals in Poland, undertaking this form of activity must take place in close cooperation with the owners and managers of the areas, and the degree of interference in the natural environment depends on the subject of the classes and their duration.
\end{abstract}

\section{Keywords}

survival, tourism impact, law regulations, protected areas 